\title{
Non-linear Effect of Exchange Rate on Economic Growth in OECD Countries Panel data analysis based on PSTR model
}

\author{
Shuning Kong ${ }^{1}$ \\ ${ }^{1}$ School of Finance Central Universiy of Finance and Economics Beijing, China
}

\begin{abstract}
Based on the panel data of 35 OECD countries from 2001 to 2019, this paper empirically analyzes the nonlinear effect of exchange rate on economic growth of countries through PSTR model. The results show that exchange rate appreciation has a certain role in promoting economic growth. When the value of the local currency is high, the exchange rate appreciation has a stronger effect on promoting economic growth; when the value of the local currency is low, the exchange rate appreciation has a weaker effect on economic growth. Further research shows that when the local currency value is low, the development of export trade has a strong positive impact on economic growth, while the inflow of FDI has a weak effect on economic growth. When the currency value is low, the promotion effect of export trade on economic growth is relatively weak, while the inflow of FDI shows a stronger promoting effect on economic development, and the nonlinear effect of exchange rate on economic growth is positive. It is the comprehensive effect of these channels.
\end{abstract}

\section{INTRODUCTION}

At present, as COVID-19 spreads globally, countries around the world are taking measures to control population mobility. As a result, economic production is putting on the brakes and the global economy is running at a low speed or even at a standstill. In the context of economic globalization, the collapse of international oil prices and the occurrence of three consecutive circuit breakers in the US stock market since February 2020 under the influence of COVID-19. In the face of the depressed economic situation under the influence of COVID-19, how to formulate relevant policies to boost the economy and how to conduct economic exchanges among countries will be a matter of great concern to all governments. As an important economic lever of a country in international exchanges, exchange rate is the core factor affecting export trade, investment development and total foreign exchange reserves. As important economic means of a country, FDI and export trade are playing an increasingly important role in domestic economic growth. As the most developed countries and regions in the world today, OECD countries play a major role in the world's outbound investment and export trade, and play a pivotal role in the operation of the world economy. Therefore, taking OECD countries as the object of study analyzed the impact of exchange rate levels on economic growth, as well as the heterogeneous impact of FDI inflows and export trade on economic growth of OECD countries at different exchange rate levels. The research results will have important guiding significance for the recovery of the world economy affected by the epidemic as soon as possible.

\section{THE CURRENT SITUATION AND EXISTING PROBLEMS}

Through literature review, it is found that the impact of exchange rate on economic growth mainly starts from the level change and fluctuation of the real exchange rate. Among which the core is the discussion on how the appreciation (or depreciation) of the real exchange rate affects the economic growth of the host country (region), however, no consistent conclusions have been reached. Some studies have confirmed the promoting effect of real exchange rate depreciation on economic growth[1]. However, some scholars have reached inconsistent conclusions. Fung' s research results showed that the real currency appreciation led to the expansion of the scale of surviving enterprises, which produced obvious scale effect, thus improving productivity and promoting economic growth[2]. Zhao Wenjun found in his research that the total effect of real exchange rate appreciation is that appreciation contributes to the transformation of economic growth pattern at both the Chinese and regional levels[3]. The most famous theory about FDI affecting the economic growth of host country (region) is "gap theory". Chenery believed that the economic growth of developing countries was restricted by the "savings gap" and the "foreign exchange gap" and could be alleviated through the introduction of foreign capital[4]. 
Haskel et al., based on the data of British manufacturing industry from 1973 to 1992, found that FDI helped domestic enterprises to improve total factor productivity[5]. Kwan\& Cotsomitis found that the relationship between export trade and economic growth was uncertain in different time periods[6]. In the process of international technology diffusion, promoting domestic technological progress through export trade, increasing total factor productivity (TFP) through spillover effects. Thereby improving the domestic industrial structure has become an important channel for export to promote economic growth.

In terms of research methods, since the impact of exchange rates on economic growth is relatively complex, the process of exchange rates on economic growth may involve the interaction of multiple macroeconomic indicators. Some scholars with nonlinear method to study on the relationship between the exchange rate and economic growth[7]. Therefore, in the domestic research on exchange rate nonlinear effect on economic growth is not sufficient. And domestic scholars studying the nonlinear effect is generally by means of introducing interactive items in the model method to do, but to join the two variables in the model in the interaction of the item, This often leads to more complex relationships between variables and does not distinguish between the subjects of the interaction. Therefore, this paper draws on the methods provided by Gonzalez et al and uses PSTR model to analyze the nonlinear effect of real effective exchange rate on economic growth in OECD countries[8].

\section{DAta DEClaration}

As OECD countries are all composed of marketing economic countries, and the developed countries are the main member countries, which play an important role in the process of global economic development. Therefore, this paper selects OECD member countries as research samples. By using GDP of each country as the proxy variable of economic growth, and selecting the bilateral exchange rate of each country's currency against the US dollar as the core explanatory variable. Secondly, it selects FDI, export trade, fixed asset investment, government investment, infrastructure construction and higher education enrollment rate as control variables. The data mainly comes from China Economic Net, the World Development Index Database and the United Nations Association for Trade and Development. The descriptive statistics of each variable is shown in TABLE I.
TABLE I. DESCRIPTIVE STATISTICS OF VARIABLES

\begin{tabular}{cccccc}
\hline Var & Obs & Mean & Std & Min & Max \\
\hline Gdp & 665 & 829.5906 & 1106.012 & 9.1545 & 6251.427 \\
Er & 665 & 64.08958 & 211.481 & 0.4975 & 1290.41 \\
Fdi & 665 & 273.2888 & 343.8834 & 0.0328 & 2100 \\
Export & 665 & 3172.921 & 12699.68 & 2.0200 & 81437.8 \\
Cap & 665 & 182.3871 & 244.1605 & 1.1088 & 1396.458 \\
Gov & 665 & 19.23573 & 3.725505 & 9.8811 & 27.935 \\
Infra & 665 & 64.45472 & 17.76822 & 10.8714 & 101.3531 \\
Human & 665 & 63.29468 & 25.03129 & 0.0000 & 146.727 \\
\hline
\end{tabular}

\section{ANALYSIS OF THE NON-LINEAR EFFECT OF EXCHANGE RATE ON ECONOMIC GROWTH}

TABLE II reports the benchmark regression results of exchange rate on economic growth. The model only controls fixed asset investment, government expenditure level, infrastructure construction level and higher education enrollment rate. From the estimation results, it can be seen that in OECD member countries, the exchange rate appreciation has a significant role in promoting economic growth, and it shows nonlinear characteristics when the exchange rate is at different levels. When the currency value is high, the exchange rate appreciation has a stronger role in promoting economic growth, and when the currency value is low, it promotes The effect is weaker. Considering that FDI and export trade are greatly affected by exchange rate, FDI and export trade have a great impact on economic growth. Therefore, this paper selects FDI and export trade as control variables, so as to eliminate the interference of these factors and analyze the impact of exchange rate on economic growth more accurately. The empirical results are shown in TABLE II (2) (3) (4). The results show that after controlling the influence of FDI, exchange rate appreciation still has a stronger promotion effect on economic growth when the currency value is high, and a weaker promotion effect when the currency value is low. After controlling the influence of export trade, exchange rate appreciation plays a weak role in promoting economic growth when the currency value is high, but it plays a stronger role in promoting economic growth when the currency value is low. Finally, when FDI and export trade are simultaneously estimated in PSTR model, the results are shown in column (4) of TABLE II. At this time, the impact of exchange rate on economic growth is still nonlinear. When the currency value is high, exchange rate appreciation has a weaker role in promoting economic growth, while exchange rate appreciation has a stronger role in promoting economic growth when currency values is low.

TABLE II. PARAMETER ESTIMATION RESULTS OF PSTR MODELS

\begin{tabular}{|c|c|c|c|c|}
\hline Var & (1) & (2) & (3) & (4) \\
\hline ER & $\begin{array}{c}-0.5066^{* * *} \\
(0.0718)\end{array}$ & $\begin{array}{l}-0.5700^{* * *} \\
(0.0492)\end{array}$ & $\begin{array}{c}-0.4150 * * * \\
(0.0429)\end{array}$ & $\begin{array}{c}-0.4861 * * * \\
(0.0258)\end{array}$ \\
\hline FDI & & $\begin{array}{l}0.1019 * * * \\
(0.0119)\end{array}$ & & $\begin{array}{c}0.0708 * * * \\
(0.0131)\end{array}$ \\
\hline Export & & & $\begin{array}{c}0.1970 * * * \\
(0.0285)\end{array}$ & $\begin{array}{c}0.1452 * * * \\
(0.0274)\end{array}$ \\
\hline
\end{tabular}




\begin{tabular}{|c|c|c|c|c|}
\hline Cap & $\begin{array}{c}0.3805 * * * \\
(0.0357)\end{array}$ & $\begin{array}{l}0.3185^{* * * *} \\
(0.0206\end{array}$ & $\begin{array}{c}0.3667 * * * \\
(0.0308)\end{array}$ & $\begin{array}{c}0.3272 * * * \\
(0.0194)\end{array}$ \\
\hline Gov & $\begin{array}{l}-0.0425 \\
(0.1044)\end{array}$ & $\begin{array}{l}-0.0583 \\
(0.0496)\end{array}$ & $\begin{array}{c}0.1281 \\
(0.0832)\end{array}$ & $\begin{array}{l}0.0718^{*} \\
(0.0408)\end{array}$ \\
\hline Infra & $\begin{array}{c}0.2186^{* * * *} \\
(0.0311)\end{array}$ & $\begin{array}{c}0.0989 * * * \\
(0.0300)\end{array}$ & $\begin{array}{c}0.0065 \\
(0.0343)\end{array}$ & $\begin{array}{l}-0.0209 \\
(0.0284)\end{array}$ \\
\hline Human & $\begin{array}{c}0.0289 \\
(0.0303)\end{array}$ & $\begin{array}{c}0.0132 \\
(0.0166)\end{array}$ & $\begin{array}{l}-0.0129 \\
(0.0301)\end{array}$ & $\begin{array}{l}-0.0066 \\
(0.0198)\end{array}$ \\
\hline \multicolumn{5}{|c|}{ Second extreme regime } \\
\hline ER & $\begin{array}{c}-0.4799 * * * \\
(0.0365)\end{array}$ & $\begin{array}{c}-0.5156^{* * *} \\
(0.0255)\end{array}$ & $\begin{array}{c}-0.4668 * * * \\
(0.0372)\end{array}$ & $\begin{array}{c}-0.4944 * * \\
(0.0248)\end{array}$ \\
\hline gamma & 131.9600 & 132.0220 & 132.4020 & 131.9600 \\
\hline c/threshold & 0.0607 & 0.0904 & -0.0070 & 0.0606 \\
\hline
\end{tabular}

Note: the value in brackets is the standard error of the estimation result, *significant at the $10 \%$ level, ** significant at the $5 \%$ level, *** significant at the $1 \%$ level, the same as following.

\section{Channel analysis of the nON-Linear EFFECT OF EXCHANGE RATE ON ECONOMIC GROWTH}

The above empirical results have shown that the exchange rate appreciation has a nonlinear effect on economic growth. It has a stronger promoting effect when the currency value is low. In order to further clarify the logic behind, this paper takes the cross multiplier of export trade, FDI and transfer function into the PSTR model to estimate, and attempts to discuss the channel of the nonlinear effect of exchange rate from these two perspectives. The results are shown in TABLE III.

TABLE III. PARAMETER ESTIMATION RESULTS OF PSTR MODELS

\begin{tabular}{|c|c|c|c|c|}
\hline Var & (1) & (2) & (3) & (4) \\
\hline ER & $\begin{array}{c}-0.5066^{* * *} \\
(0.0718)\end{array}$ & $\begin{array}{l}-0.5747^{* * * *} \\
(0.0458)\end{array}$ & $\begin{array}{c}-0.3453 * * * \\
(0.0412)\end{array}$ & $\begin{array}{c}-0.4395 * * * \\
(0.0443)\end{array}$ \\
\hline FDI & & $\begin{array}{l}0.1016 * * * \\
(0.0116)\end{array}$ & & $\begin{array}{c}0.0773 * * * \\
(0.0167)\end{array}$ \\
\hline Export & & & $\begin{array}{c}0.2008 * * * \\
(0.0278)\end{array}$ & $\begin{array}{c}0.1436 * * * \\
(0.0301)\end{array}$ \\
\hline Cap & $\begin{array}{c}0.3805 * * * \\
(0.0357)\end{array}$ & $\begin{array}{l}0.3179 * * * \\
(0.0201)\end{array}$ & $\begin{array}{c}0.3724 * * * \\
(0.0305)\end{array}$ & $\begin{array}{c}0.3304 * * * \\
(0.0204)\end{array}$ \\
\hline Gov & $\begin{array}{l}-0.0425 \\
(0.1044)\end{array}$ & $\begin{array}{l}-0.0600 \\
(0.0483)\end{array}$ & $\begin{array}{l}0.1420 * \\
(0.0806)\end{array}$ & $\begin{array}{c}0.0912 * * \\
(0.0429)\end{array}$ \\
\hline Infra & $\begin{array}{c}0.2186^{* * *} * \\
(0.0311)\end{array}$ & $\begin{array}{c}0.0988 * * * \\
(0.0301)\end{array}$ & $\begin{array}{c}0.0027 \\
(0.0333)\end{array}$ & $\begin{array}{l}-0.0244 \\
(0.0277)\end{array}$ \\
\hline Human & $\begin{array}{c}0.0289 \\
(0.0303)\end{array}$ & $\begin{array}{c}0.0153 \\
(0.0163)\end{array}$ & $\begin{array}{l}-0.0037 \\
(0.0284)\end{array}$ & $\begin{array}{l}-0.0053 \\
(0.0188)\end{array}$ \\
\hline \multicolumn{5}{|c|}{ Second extreme regime } \\
\hline ER & $\begin{array}{c}-0.4799 * * * \\
(0.0365)\end{array}$ & $\begin{array}{c}-0.5194 * * * \\
(0.0271)\end{array}$ & $\begin{array}{c}-0.4600 * * * \\
(0.0365)\end{array}$ & $\begin{array}{c}-0.4914 * * \\
(0.0262)\end{array}$ \\
\hline FDI & & $\begin{array}{c}0.1034 * * * \\
(0.0132)\end{array}$ & & $\begin{array}{c}0.0636^{* *} \\
(0.0150)\end{array}$ \\
\hline Export & & & $\begin{array}{c}0.1913 * * * \\
(0.0284)\end{array}$ & $\begin{array}{c}0.1518 * * \\
(0.0259)\end{array}$ \\
\hline gamma & 131.9600 & 131.9630 & 132.2460 & 131.9010 \\
\hline c/threshold & 0.0607 & 0.0945 & -0.0763 & -0.0808 \\
\hline
\end{tabular}

It can also be seen from TABLE III that the change of of FDI on economic growth does not change exchange rate level can indeed affect the influence of FDI and export trade on economic growth. The inflow of FDI in a country is of great significance to the domestic industrial structure, resource allocation and production efficiency. As the external price of a country's currency, the impact of the change of exchange rate level on FDI cannot be ignored. OECD member countries have relatively developed economies and higher infrastructure levels. When the currency value is high, the wealth effect of their own currency is higher, and the inflow of FDI has a stronger effect in promoting economic growth. When the currency value is low, the situation is the opposite. In the empirical results in column (2) of TABLE III, since export trade is uncontrolled, the impact significantly when the exchange rate changes. However, after controlling both FDI and export trade in column (4) of TABLE III, it is obvious that when the local currency value is high, FDI has a stronger effect on promoting economic growth, and when the local currency value is weak, FDI has a weaker effect on economic growth.

Under the condition of open economy, the depreciation of exchange rate will lead to relatively cheap export price, which is conducive to promoting export. As one of the "troika" driving GDP growth, the change of export trade will inevitably affect the development of a country's economy directly. When the value of domestic currency is high, the price of domestic goods will be relatively high, which will lead to the 
decline of export trade volume. The promotion effect of development is weak, but when the currency value is low, the export volume is relatively easy. At this time, export trade has a stronger effect in promoting economic development. The empirical results in column (4) of TABLE III also show that the development of export trade can promote economic growth, and the promotion effect is stronger when the local currency value is low. When the value of the local currency is high, the promotion effect is weak.

\section{CONCLUSION}

Taking OECD countries as research samples, this paper empirically analyzes the non-linear impact of exchange rate on economic growth of each country through PSTR model, that is, the impact of exchange rate on economic growth and the specific channels of influence when the exchange rate is at different levels. The results show that exchange rate appreciation has a certain role in promoting economic growth, and shows a non-linear effect. That is, when the local currency value is high, the exchange rate appreciation has a stronger effect on promoting economic growth. When the local currency value is low, the exchange rate appreciation has a weaker effect on economic growth. Furthermore, this paper discusses the channels of non-linear impact of exchange rate on economic growth from the perspectives of FDI and export trade respectively. When the currency value is low, the development of export trade has a strong positive impact on economic growth, while the inflow of FDI has a weak effect on economic growth; when the currency value is low, the promotion effect of export trade is relatively weak, and the inflow of FDI on economic development is relatively weak. The non-linear effect of exchange rate on economic growth is the comprehensive effect of these channels.

\section{REFERENCES}

1. Rapetti M., Skott P., Razmi A.. The real exchange rate and economic growth: are developing countries differen?[J]. International Re-view of Applied Economics, 2012,26 (6) :735-753.

2. Fung L.. Large Real Exchange Rate Movements, Firm Dynamics, and Productivity Growth[J]. The Canadian Journal of Economics / Revue canadienne d'economique, 2008, 41(2):391-424.

3. Zhao W J. Appreciation of Real Exchange Rate and Transformation of EconomicGrowth Pattern: An Empirical Analysis Based on China's 1995-2012Provincial Panel Data [J]. Journal of International Trade,2014(03):131-143.

4. Chenery H B.. Foreign assistance and economic development: Comment[J]. American Economic Review, 1968, 58(4):897-912.

5. Haskel J E, Pereira S C , Slaughter M J . Does Inward Foreign Direct Investment Boost the Productivity of Domestic Firms?[J]. Review of Economics \& Stats, 2007, 89(3):482-496.

6. Kwan A C C, Cotsomitis J A. Economic Growth and The Expanding Export Sector: China 1952-1985[J]. International Economic Journal, 1991, 5(1):105-116.

7. Cheng L Y, Li J K. Does the abnormal flow of international capital have a nonlinear effect on economic growth? _-Based on the perspective of exchange rate system and financial market development [J]. Study of International Finance, 2020 (04): 43-53.

8. Gonzalez A, Timo Teräsvirta, Dijk D V, et al. Panel Smooth Transition Regression Models[R].Department of Economics and Business Economics, Aarhus University.2017. 